\title{
Menyoal Radikalisme di Media Digital
}

\author{
Ahmad Zamzamy \\ Fakultas Ilmu Sosial dan IImu Politik \\ Universitas Pembangunan Nasional Veteran Jawa Timur \\ akhi_zamy@yahoo.co.id
}

\begin{abstract}
Currently, Information and communication technology, especially internet system, have been developing very rapidly. Such developments have certainly positive and negative impacts. In the development of the digital age today, phenomenon of radicalism is increasingly established in Indonesia and the world. There have been many studies on this. Radicalism is also campaigned by internet media which eventually step into people's life. This issue should be observed properly.
\end{abstract}

Key Words: Radicalism, Digital Media, Youth Generation

\section{PENDAHULUAN}

Dalam era digital ini, fenomena radikalisme beberapa waktu terakhir ini makin marak menggejala dan terjadi di dunia maupun di Indonesia. Banyak tulisan yang sudah mengupas dan membahas mengenai hal tersebut. Definisi mengenai radikalisme ternyata masih belum ada satu titik temu. Pada umumnya kebanyakan orang menganggap radikalisme sama dengan terorisme. Biasanya radikalisme diidentikkan dalam bentuk kekerasan dan dampaknya merugikan orang banyak. Radikalisme bisa terjadi di dunia nyata maupun di dunia virtual. 
Dalam perkembangan aktual, beberapa pemuda di beberapa kota besar, seperti Jakarta dan Malang melakukan baiat kepada ISIS. Sebagian besar individu yang berangkat tersebut merupakan anak muda. Di lain pihak, dalam beberapa kasus di tingkat sekolah dasar-menengah, ditemukan beberapa buku yang mengajarkan nilainilai radikalisme. Sedangkan di tingkat perguruan tinggi, Menteri Riset, Teknologi, dan Pendidikan Tinggi menyatakan bahwa kampus-kampus besar di Indonesia telah terpapar paham radikalisme. Kepala BIN menyatakan bahwa 39\% mahasiswa seIndonesia telah terpapar paham radikalisme. Karena itu, Departemen Pertahanan RI, dalam Buku Putih Pertahanan tahun 2008 menyebutkan bahwa ancaman teraktual bagi Indonesia bukan semata-mata ancaman secara fisik, tetapi juga ancaman dari pemikiran radikalisme. Menariknya, dari berbagai hasil penelitian diungkapkan bahwa generasi muda rentan terhadap provokasi kelompok radikal. Radikalisme menjadi isu kontemporer yang selalu aktual karena menemukan relevansinya dengan banyak kasus. Terlebih dengan terjadinya kasus terorisme yang masih sering terjadi. Yang menarik, radikalisme turut melibatkan banyak generasi muda.

Secara etimologi, terma radikalisme berasal akar kata radix, yang artinya bertindak radikal dan dapat juga berarti sampai ke akar-akarnya (Echols dan Shadily, 1995). Radikalisme dapat dipahami sebagai suatu sikap atau posisi yang mendambakan perubahan terhadap status quo dengan jalan menghancurkannya secara total dan menggantinya dengan sesuatu yang baru, yang sama sekali berbeda. Biasanya cara yang digunakan bersifat revolusioner, artinya menjungkirbalikkan nilai-nilai yang ada secara drastis lewat kekeraan (violence) dan aksi-aksi yang ekstrim (Juergensmeyer, 2002). Saat ini, biasanya radikalisme disangkutpautkan dengan agama. Secara filosofis, fenomena radikalisme agama merupakan persoalan yang berhubungan dengan pengalaman inti (core experience), memori kolektif (collective memory) dan penafsiran (interpretation) agama (Banawiratma, 1993). Adapun latar munculnya radikalisme secara sosiologis-empiris tidak dapat dipisahkan dari dinamika internal masyarakat itu sendiri. Hal tersebut dilatarbelakangi oleh adanya sejumlah faktor yang melingkupinya baik internal maupun eksternal. 
Radikalisme menjadi topik perdebatan hangat di kalangan ilmuwan dan para filsuf. Di satu sisi, fundamentalisme yang berujung kekerasan dipandang sebagai akibat dari modernitas. Sosiolog Max Weber yang mewakili sisi ini menilai modernitas juga sesungguhnya menjadi dapur gerakan radikal-fundamentalis. Dengan modernitas, ideal akan harmoni kosmik hilang dan dunia hanya berupa obyek eksternal yang bisa dipakai untuk tujuan-tujuan utilitaristis. Di sisi lain, filsuf Juergen Habermas melihat pelbagai gerakan fundamentalis-radikal lebih sebagai bukti "kegagalan" untuk masuk komunitas plural dan modern. Menurut Habermas, setiap agama atau kelompok spiritual tertentu pasti bersifat dogmatis dalam ajarannya dan oleh karena itu membutuhkan otoritas berwenang untuk menafsir sekaligus menetapkan mana yang ortodoks (legal) dan yang bukan. Di tengah masyarakat yang plural dan modern, ortodoksi seperti itu bisa berbuah fundamentalisme jika situasi epistemik masyarakat plural dan modern diabaikan. Situasi epistemik yang dimaksudkan Habermas adalah bagaimana setiap kelompok bisa merelativisasikan posisinya vis a vis di antara kelompok lain tanpa merelativisasikan dogmanya sendiri (Borradori, 2003).

Fenomena radikalisme ini bisa dikaji dengan filsafat analitis bahasa. Di dalam bahasa terorisme terdapat kemiripan keluarga (family resemblance), sebagai analogi di dalam satu bentuk tata permainan bahasa yang sama. Hal ini berarti teori Wittgenstein II yang menyatakan, bahwa "Aneka Kemiripan Keluarga” terdapat di dalam berbagai bentuk tata permainan bahasa yang lebih dari satu, tidak berlaku dalam konteks terorisme. Para subyek yang melakukan terorisme sama-sama mengacu kepada Tuhan dalam melakukan kejahatan mereka. Hal tersebut tampak dari ungkapan yang terlontar: "Semoga Allah meridhai kita" dan juga "May God Bless America" (Hendropriyono, 2009). Hal tersebut berarti terorisme dilakukan oleh para subyek yang sama-sama merupakan individu-individu penganut agama. Penggunaan ungkapan bahasa yang baru mempunyai rule of the game tertentu yang baru pula (Wittgenstein, 1983).

Berawal dari kaum-kaum konservatif terutama yang memegang teguh nilai-nilai agama sebagai patokan dasar setiap individu berbuat dan berperilaku, lahirlah para tokoh-tokoh fundamentalis yang medasarkan tindakannya pada nilai-nilai fundamental 
yang ada. Giddens menyebutkan dalam bukunya mengenai peristiwa revolusi Iran yang dipimpin oleh Ayatollah Khomeini yang menjadikan basis fundamental agama menjadi sebuah kekuatan tandingan dari kekuasaan pemerintah. Khomeini menyebarkan ajaran dan mengundang massa melalui video dan kaset yang disebar. Ini merupakan salah satu contoh tindakan ekstensif dari para fundamentalis dalam mempertahankan tradisitradisi, khususnya dalam bidang agama. Selain usaha yang dilakukan Khomeini masih banyak kejadian lain di mana seseorang revolutor meyebarkan paham dan ajarannya melalui media-media informasi modern yang semakin mudah menyebar bahkan hingga ke seluruh dunia karena adanya fenomena globalisasi.

Fundamentalisme dianggap sebagai sebuah pemikiran yang tidak dapat dipertanyakan. Fundamentalis tidak hanya selalu berbicara soal agama. Namun fundamentalis berbicara soal kepercayaan. Fundamentalis berfokus pada "mengapa manusia percaya?" (Giddens, 2002). Manusia dengan rasa percaya dalam hatinya tidak dapat mempertanyakan apa yang mereka percaya, namun ia hanya mendasarkan perbuatannya itu pada kepercayaan hati nuraninya yang melampaui nilai kerasionalitasan suatu obyek. Fundamentalis mengusung nilai-nilai kelompok yang berlaku pada suatu komunitas sosial. Fundamentalis menolak hal-hal yang bersifat universal seperti yang dipercayai oleh para pemaham cosmopolitan.

Pertentangan yang menimbulkan kekerasan sering terjadi di dunia ini, termasuk pada fenomena globalisasi. Globalisasi yang dianggap sebagai usaha pengglobalan dunia menyebaban adanya kekhawatiran terhadap lunturnya tradisi-tradisi dari masingmasing komunitas yang akan digantikan dengan nilai-nilai unversal. Namun pada kenyataannya tradisi dan adat tidak mudah tergerus begitu saja. Keberadaan kaum konservatisme yang senantiasa memegang teguh tradisi dan ajaran-ajaran fundamental menyebabkan tradisi tidak begitu saja dapat digoyahkan oleh arus kuat perkembangan ilmu pengetahuan yang kian lama kian terbuka dan menunjukkan progress besar.

Perjuangan kaum konservatif dalam mempertahankannya didukung dengan kemunculan kelompok-kelompok fundamentalis yang dicontohkan Giddens dengan Ayotollah Khomeini. Kaum-kaum fundamentalis yang melakukan perjuangannya melalui cara- cara ekstensif dengan membentuk pasukan- pasukan bersenjata sebagai jalan 
menuju sebuah revolusi. Pertentangan besar yang sempat dilakukan gereja untuk memerangi kaum illuminati juga sempat terjadi pada masa kejayaan Renaissance di mana banyak ilmuwan lahir dan mengungkap segala misteri mengenai alam semesta.

\section{PEMBAHASAN}

\section{Magnet Radikalisme}

Sejak lama, penelitian tentang radikalisme maupun deradikalisasi menjadi magnet bagi para ilmuwan, termasuk dari mereka yang berasal dari Indonesia. Penelitian yang berjudul Terorisme dan Deradikalisasi: Pengantar Memahami Fundamentalisme Islam dan Strategi Pencegahan Aksi Terorisme oleh Tamat Suryani (2017) membahas mengenai dampak terorisme dan cara penanggulangannya. Salah satu cara memerangi terorisme adalah deradikalisasi.

Sementara itu, pada penelitian yang berjudul Pengembangan Pendidikan Aswaja Sebagai Strategi Deradikalisasi oleh Ngainun Naim (2015) mengulas tentang peranan pelajaran Aswaja dalam usaha deradikalisasi. Aswaja diyakini dapat mencegah tumbuh suburnya radikalisasi. Data yang disajikan dalam artikel ini berasal dari observasi, wawancara dan telaah literatur yang berkaitan dengan topik tulisan. Deradikalisasi dalam penelitian tersebut membahas dari sisi pendidikan yang bernilai Aswaja, sedangkan penelitian yang akan dilakukan penulis dari sisi teks digitalnya.

Penelitian yang berjudul Media Literasi dalam Kontra Propaganda Radikalisme dan Terorisme melalui Media Internet oleh Benedicta Dian Ariska Candra Sari (2017) mengatakan bahwa media literasi menjadi solusi untuk meningkatkan pertahanan diri masyarakat terhadap terpaan propaganda radikalisme dan terorisme melalui media internet. Hal lain yang harus ditingkatkan dalam hal penanggulangan radikalisme dan terorisme adalah kesadaran masyarakat bahwa pencegahan radikalisme dan terorisme bersifat semesta. Artinya bahwa seluruh elemen masyarakat bertanggung jawab dalam menanggulangi kejahatan terorisme. 
Penelitian berikutnya berjudul Melawan Radikalisme melalui Website oleh Rina Sari Kusuma dan Nur Azizah (2018) ini juga melihat perlawanan terhadap radikalisme yang dilakukan oleh Badan Nasional Penanggulangan dan Terorisme (BNPT) bekerjasama dengan Pusat Media Damai (PMD) dengan ketiga websitenya. Adapun ketiga website tersebut adalah jalandamai.org, damailahindonesiaku.com, dan damai.id. Penelitian ini menggunakan teknik analisis isi kualitatif.

Penelitian yang berjudul Peran Pemerintah Menanggulangi Radikalisme Dan Terorisme Di Indonesia oleh Sitti Aminah (2016) mendeskripsikan faktor-faktor penyebab dan merumuskan langkah-langkah yang dilakukan pemerintah untuk penanggulangan radikalisme dan terorisme di Indonesia. Hasil kajian menunjukkan terdapat multi faktor penyebab radikalisme dan terorisme. Dari perspektif sosial politik, radikalisme timbul karena adanya dominasi kelompok pada suatu sistem dan kesenjangan yang tajam di masyarakat sehingga menimbulkan fatalisme.

Perspektif sosiologis, pemicu radikalisme adalah krisis identitas yang menimpa generasi muda, ketergoncangan moral dan perbedaan ideologi dan jaringan sosial. Pemicu dari perspektif ekonomi adalah kesenjangan ekonomi yang menimbulkan kecemburuan sosial. Peran Pemerintah untuk menanggulangi radikalisme dan aksi-aksi terorisme melalui upaya: penguatan kebijakan, penguatan institusi pendidikan formal, penataan pemanfaatan media, perubahan pola deradikalisasi, meningkatkan perekonomian masyarakat dan melakukan strategi pencegahan melalui deteksi dini.

Pada penelitian yang berjudul Deradicalization: Different Approaches oleh Daniela Ștefănescu (2015) menyebutkan bahwa pencegahan radikalisasi bisa dilakukan melalui ruang virtual. Penelitian ini membahas strategi deradikalisasi yang dilakukan oleh beberapa pemerintah di negara Timur Tengah, Asia Tenggara dan Eropa.

Lalu ada pula penelitian dari luar egeri berjudul Deradicalization: Using Triggers for the Development of a US Program oleh Stefanie Mitchell (2016) membahas dan meninjau panduan untuk Program Deradikalisasi AS yang perlu disempurnakan. Penelitian ini menggunakan analisis konten lintas-nasional kualitatif dari narasi mantan 
teroris, evaluasi struktur program deradikalisasi internasional dan temuan penelitian utama.

Penelitian selanjutnya berjudul Terrorist Deradicalisation Programme in Malaysia: A Case Study oleh Mohd Norzikri Kamaruddin, Noor Nirwandy Mat Noordin, dan Abd Rasid Abd Rahman (2017) membahas usulan program deradikalisasi kepada pemerintah Malaysia dengan Model Deradikalisasi Wasatiyyah. Penelitian ini menggunakan metodologi studi kasus kualitatif dengan melakukan wawancara mendalam kepada pihak yang berwenang, akademisi, dan mantan teroris untuk mengeksplorasi solusi untuk radikalisasi.

Berikutnya, penelitian yang berjudul Counter-Productive Counter-Terrorism. How is the dysfunctional discourse of Prevent failing to restrain radicalisation? oleh Lauren Powell (2016) mengupas mengapa rantai pencegahan strategi kontraterorisme Pemerintah Inggris gagal mencapai keberhasilan dalam mengurangi radikalisasi pemuda Muslim dan rekomendasi pencegahannya.

Adapun penelitian yang berjudul Toward a Framework Understanding of Online Programs for Countering Violent Extremism oleh Garth Davies, Christine Neudecker, Marie Ouellet, Martin Bouchard dan Benjamin Ducol (2016) membahas pentingnya peran internet dalam program Countering Violent Extremism (CVE). Penelitian ini mencoba untuk membangun landasan dan kerangka kerja untuk program-program ini: pertama, dengan mengidentifikasi konsep dan konstruksi yang mungkin paling relevan untuk melawan ekstremisme kekerasan online, dan kedua, dengan memeriksa materi yang tersedia dari enam program CVE online sehubungan dengan konsep-konsep ini.

\section{Radikalisme dan Agama}

Radikalisme adalah salah satu manifestasi dari fundamentalisme. Dalam trend kontemporer, radikalisme yang berbentuk radikalisme agama. Geles Kepel misalnya, menjelaskan dalam referensinya The Revenge of God, mengenai fenomena radikalisme di kalangan agama-agama. Agama yang diprediksi akan mengalami penurunan pada era 
modernisasi, justru mengalami hal yang sebaliknya. Agama menampilkan diri sebagai salah satu kekuatan penggerak massa yang besar. Tokoh-tokoh seringkali melakukan mobilisasi politik dan perubahan radikal dengan beralasankan agama. Agama menjadi kekuatan yang bagi sebagian agama dinyatakan sebagai sebuah fenomena radikalisme. Namun yang menarik adalah fenomena radikalisme semakin mudah diterima di kalangan generasi muda. Schmit \& Cohen (2015) menyatakan mudahnya kelompok yang diindikasikan radikal menyebarkan paham radikalisme seiring dengan kemajuan teknologi informasi. Berbagai laman di internet terindikasi menjadi sarana penyebaran radikalisme di kalangan generasi muda.

Salah satu gerakan yang dianggap merupakan radikalisme agama adalah ISIS. Ia juga dianggap mengambil posisi pada kelompok ekstremisme kanan. Munculnya radikalisme agama disebut sebagai respons postmodernis atas modernitas. Disebut respons postmodernis karena radikalisme agama lahir akibat adanya patologi modernitas. Akibat patologi tersebut, modernitas kemudian melahirkan perlawanan yang salah satu bentuknya berupa radikalisme. Mengapa demikian? Alasannya karena modernitas dinilai cenderung meminggirkan aspirasi keagamaan dan menjadikan masyarakat tercerabut dari akar-akar identitasnya, baik dalam kehidupan sehari-hari hingga tata sosiopolitik. Tercerabutnya masyarakat dari akar identitas tersebut kemudian menyisakan ruang kosong yang diisi dengan munculnya fundamentalisme dan ekstremisme yang acap kali radikal. Atas dasar itu, agama kemudian merespons dalam wujud kebangkitan Islam, misalnya, untuk menunjukkan bahwa Islam bukan sebatas agama dan ibadah personal, tetapi juga sebagai the way of life.

Modernitas di sini dapat dimaknai sebagai bentuk dari arus globalisasi. Beberapa pihak memandang globalisasi justru meningkatkan ketegangan kultural dan memunculkan perlawanan karena dinilai mengikis identitas kultural. Menurut pandangan ini, globalisasi yang identik dengan kemajuan teknologi malah menghasilkan suatu pergesekan yang selanjutnya memperkuat beberapa pihak untuk melakukan perlawanan atas dominasi budaya dan identitas dari luar terhadap budaya dan identitas yang dimiliki. 
Oleh Benjamin Barber, kenyataan tersebut dianalogikan sebagai perlawanan “jihad” versus McWorld yang berada pada posisi diametral dan saling berlawanan. Menurut Giddens, hal itu terjadi karena globalisasi tidak hanya menarik ke atas, melainkan juga mendorong ke bawah dan menekan ke samping. Menarik ke atas dalam arti bahwa globalisasi menggiring bangsa dan komunitas lokal memasuki arena global. Mendorong ke bawah yakni menciptakan tekanan baru bagi otonomi lokal, di mana globalisasi menjadi alasan bagi kebangkitan kembali identitas budaya di berbagai belahan dunia. Pada titik itulah, munculnya ekstremisme dan radikalisme berbasis agama dapat dikatakan tidak terlepas dari konsekuensi globalisasi dan simbol-simbol modernitas yang menyertainya.

\section{Deradikalisasi dan Media Digital}

Deradikalisasi menurut Pusat Pengembangan Data dan Informasi (Pusbangdatin) Hukum dan HAM Balitbangkumham adalah tindakan pencegahan aksi terorisme atau stratregi dalam menetralisir paham-paham yang dianggap radikal serta membahayakan melalui pendekatan tanpa kekerasan atau soft power. A.S. Hikam mengatakan bahwa ada dua makna secara implisit dalam deradikalisasi yaitu pemutusan dan deideologisasi. Pemutusan bisa berarti mendorong individu atau kelompok yang berpaham radikal untuk melakukan orientasi diri melalui perubahan sosial kognitif.

Hal ini bertujuan agar mereka bisa meninggalkan pemahaman radikal yang mereka anut sebelumnya menuju norma baru - dalam hal ini pemikiran yang tidak radikal. Adapun deideologisasi merupakan penghapusan ideologi atas nama agama dan agama tidak dipandang sebagai ideologi politik. Akan tetapi, agama dapat dipahami sebagai nilai-nilai luhur yang menyemai pesan perdamaian. Dari makna di atas bisa disimpulkan bahwa deradikalisasi dilakukan dalam jangka waktu yang panjang. la bekerja di tingkat ideologi dengan tujuan mengubah doktrin dan interpretasi pemahaman radikal. Deradikalisasi berarti upaya sistematis untuk mengubah atau menghilangkan radikalisme. Deradikalisasi dunia maya berarti suatu upaya sistematis yang ingin mengubah dunia maya saat ini penuh dengan konten radikal menjadi tidak 
radikal atau melawan pengaruh konten radikal di dunia maya untuk tidak mempengaruhi para pembaca dan penggunanya.

Menurut A.S Hikam, ada tiga subyek dalam proses deradikalisasi ini dalam bukunya yang berjudul “Peran Masyarakat Sipil Indonesia Membendung Radikalisme Deradikalisasi”. Pertama adalah suprastruktur. Ini merujuk pada pemerintah pusat maupun pemerintah daerah. Peran suprastruktur ini didukung oleh beberapa peraturan atau undang-undang seperti UU No. 15/2003 tentang Pemberantasan Tindak Terorisme, UU No. 15/2003 tentang TNI yang mengamanatkan penghadapan ancaman atas negara dari pelaku non-negara, UU No. 3/2002 tentang Pertahanan Nasional, Peraturan Presiden Nomor 12/2002 tentang Pertahanan Nasional Penanggulangan Terorisme, sampai UU No. 17/2013 tentang Organisasi Kemasyarakatan yang melarang ideologi kontra Pancasila.

Kedua adalah infrastruktur yang meliputi lembaga/organisasi pelaksana deradikalisasi baik dari unsur pemerintah maupun masyarakat. Terakhir adalah substruktur. Ini meliputi individu-individu yang turut serta terlibat dalam infrastruktur deradikalisasi. Ada beberapa pendekatan agar program deradikalisasi bisa berjalan sukses, yaitu pendekatan humanis, pendekatan komunikasi sosial, dan pendekatan partisipatif dari elemen masyarakat.

Media digital adalah media yang dikodekan dalam format mesin yang dapat dibaca (machine-readable) Konsep Media Digital adalah biner yaitu 0 dan 1 menggunakan gelombang diskrit. Media digital dapat dibuat, dilihat, didistribusikan, dimodifikasi dan bisa bertahan pada perangkat elektronik digital. Proses digital menggunakan logika Alogaritma. Program-program komputer dan perangkat lunak seperti citra digital, digital video; video games; halaman web dan situs web, termasuk media sosial; data dan database; digital audio, seperti mp3, mp4 dan e-buku adalah contoh media digital. Media digital sangat berbeda dengan media analog yang mengandalkan sistem manual seperti media cetak, buku cetak, surat kabar dan majalah yang masih bersifat tradisional seperti gambar, film tape audio dan lain-lain (University of Guelph, September 2006)

Dalam era modern kombinasi antara Internet dan komputasi personal, menyebabkan media digital membawa dampak dan masalah dalam dunia penerbitan, 
jurnalistik, hiburan, pendidikan, perdagangan dan politik. Media Digital juga telah menimbulkan tantangan baru terutama bagi hukum yang melindungi hak cipta dan kekayaan intelektual, dalam gerakan konten terbuka di mana pencipta konten dengan sukarela menyerahkan sebagian atau seluruh hak-hak hukum mereka untuk pekerjaan mereka. Kini Media digital sudah memasuki sendi-sendi kehidupan masyarakat dan dampaknya telah terasa bagi masyarakat luas dan itu menunjukan bahwa media digital adalah awal sebuah era baru dalam sejarah industri yang disebut era Informasi, dan telah mengarah ke masyarakat paperless di mana semua produk inforamsi pada media yang diproduksi dan dikonsumsi berbasis komputer. Namun, tantangan menuju transisi media digital, termasuk produk undang-undang yang mengatur hak cipta, sensor, digital divide, adalah momok menuju era kegelapan digital (digital dark age) di mana media yang lebih tua menjadi tidak dapat diakses ke sistem baru atau tidak bisa diupgrade ke sistem informasi. Sedangkan media-media digital yang signifikan, luas dan kompleks telah memberi dampak pada masyarakat dan budayanya. Oleh karena itu, pemanfaatan media digital untuk membendung terorisme, termasuk buat menggencarkan upaya deradikalisasi, merupakan keniscayaan.

Media internet kadang digunakan untuk meningkatkan propaganda, membangun jaringan, mengkomunikasikan antarjaringan, dan sarana rekrutmen baru dari sel-sel terorisme. Ada istilah cyberterrorism yang dikemukakan oleh Barry Collin tahun 1997. la mendefinisikannya sebagai konvergensi sibernetik dengan terorisme. Media internet memiliki peranan yang sangat signifikan bagi kelompok radikal. Kesadaran pentingnya media sebagai alat propaganda oleh kelompok radikal teroris telah dimulai sejak lama. Mereka memiliki ribuan situs dengan berbagai bahasa sebagai alat propaganda. Dengan adanya media sosial, semua kalangan masyarakat - terutama pemuda - bisa mengakses situs radikal, chat via online, dan aktivitas lainnya di dunia maya yang memungkinkan terjadinya proses radikalisasi.

Untuk meminimalisir kemunculan dan dampak radikalisme, ada suatu program yang dinamakan dengan deradikalisasi. Pemerintah melalui Badan Nasional Penanggulangan Terorisme memiliki program deradikalisasi. Di Indonesia, program deradikalisasi ditujukan kepada pencapaian dua tujuan utama. Pertama, kelompok inti 
dan pendukung agar meninggalkan cara-cara kekerasan dan teror dalam memperjuangkan misinya. Kedua, baik kelompok inti, pendukung dan simpatisannya agar memoderasi paham-paham radikal mereka seturut dengan paham kelompok Islam yang moderat dan cocok dengan nilai-nilai NKRI.

Adapun tujuan program deradikalisasi yang dilakukan oleh BNPT adalah:

- Membina narapidana terorisme agar meninggalkan pandangan, pemikiran, sikap, dan tindakan radikal terorisme melalui pendekatan agama, sosial, budaya, dan ekonomi;

- Memberikan pencerahan pemikiran kepada narapidana terorisme dengan pengetahuan agama yang damai dan toleran serta wawasan kebangsaan dalam kerangka Negara Kesatuan Republik Indonesia;

- Membina kemandirian kepada narapidana terorisme berupa pembekalan keterampilan, keahlian, dan pembinaan kepribadian;

- Mempersiapkan narapidana terorisme sebelum kembali dan hidup berdampingan dengan masyarakat;

- Membina dan memberdayakan keluarga narapidana terorisme dan masyarakat agar dapat menerima kembali mantan narapidana teroris untuk dapat bersosialisasi di tengah masyarakat;

- Memberdayakan mantan narapidana terorisme, keluarga, dan masyarakat dengan pendekatan agama, sosial, pendidikan, budaya, dan ekonomi; dan

- Memberdayakan masyarakat dalam rangka meninggalkan paham dan sikap radikal terorisme yang berkembang di tengah masyarakat.

Pelaksanaan deradikalisasi di Indonesia dirumuskan sebagai suatu program yang utuh, integratif, dan berkesinambungan dengan dua klasiifikasi, yaitu Deradikalisasi di Dalam Lapas dan Deradikalisasi di Luar Lapas. Deradikalisasi di Dalam Lapas meliputi tahap identifikasi, rehabilitasi, reedukasi, resosialisasi, dan monitoring serta evaluasi. Deradikalisasi di dalam Lapas memiliki sasaran para Narapidana tindak pidana terorisme yang tersebar di berbagai lapas di Indonesia. Sedangkan Deradikalisasi di Luar Lapas 
mencakup tahap identifikasi, pembinaan kontra radikalisasi, dan monitoring serta evaluasi. Deradikalisasi di luar Lapas memiliki sasaran yaitu:

- Individu, yaitu seseorang yang diindikasikan berpikiran radikal-teroris;

- Kelompok, yaitu sekumpulan orang yang bergabung dalam organisasi yang diindikasikan berpikiran radikal-teroris;

- Keluarga, yaitu keluarga inti dari individu atau kelompok yang terindikasi radikal. Keluarga ini juga dapat diperluas pada keluarga terdekatnya jika dipandang bahwa keluarga terdekat tersebut juga terindikasi berpaham radikal atau memberikan dukungan terhadap paham/aksi radikal terorisme; dan

- Mantan Napi Teroris, yaitu orang yang telah bebas dari lapas sebagai napi teroris.

Ada kebijakan deradikalisasi dunia maya:

- Melakukan perlawanan narasi yang disebarkan oleh kelompok radikal teror.

- Mencegah proses radikalisasi yang terjadi melalui media internet.

- Mencegah konten-konten negatif yang berupa ptovokasi, penyebaran kebencian, permusuhan, dan ajakan kekerasan yang mengarah pada tindakan teror.

- Membentengi masyarakat dari keterpengaruhan ideologi dan indoktrinasi kelompok teror melalui dunia maya.

- Meningkatkan pengetahuan masyarakat untuk menolak paham teror.

- Memperkaya khazanah pengetahuan masyarakat dengan perbandingan informasi yang kredibel dan konten edukatif yang mencerahkan.

- Menjalin sinergitas seluruh komponen bangsa, khusus para pegiat dunia maya, dalam mencegah penyebaran paham dan ideologi radikal.

Kasus cyberterrorism yang dibongkar pertama kali di Indonesia melibatkan Imam Samudra. Ternyata meskipun dalam lapas Kerobokan, Bali, dia mulai aktif di dunia maya dan mengendalikan jaringannya menjelang peledakan Bom Bali jilid 2 tahun 2005. Akhirnya dia dipindah ke Nusa Kambangan. 
Pada tahun 2015, BNPT melakukan beberapa langkah sebagai upaya deradikalisasi, di antaranya:

1. Membentuk dan mengoperasikan lembaga Pusat Media BNPT. Adapun tugasnya adalah:

a. Melakukan monitoring dan analisis perkembangan propaganda media radikal.

b. Melakukan riset media dalam rangka menganalisis kecenderungan dan persepsi masyarakat dari keterpengaruhan ajaran dan paham kelompok radikal teroris.

c. Mengelola website yang bersifat informatif melalui www.damailahindonesiaku.com.

d. Mengelola website yang bersifat edukatif melalui www.jalandamai.org.

e. Mengelola portal komunitas damai melalui www.damai.id.

2. Melakukan literasi media kepada generasi muda melalui Workshop Program Damai di Dunia Maya.

3. Melakukan kontra narasi melalui rilis media.

4. Menerbitkan publikasi cetak dan produksi audio-visual.

Selain pemerintah melalui BNPT, upaya deradikalisasi juga dilakukan oleh keluarga, tokoh agama, lembaga pendidikan dan Komunitas Penggiat Dunia Maya. Di antara pihak-pihak yang melakukan upaya deradikalisasi tersebut, ada beberapa yang didirikan dan diinisiasi oleh para mantan radikal teroris. Mereka adalah Pondok Pesantren Al-Hidayah di Deli Serdang; Yayasan Prasasti Perdamaian di Jakarta; dan Yayasan Lingkar Perdamaian di Lamongan. 


\section{KESIMPULAN}

Dalam beragam kasus, radikalisme menyasar generasi muda. Keterlibatan generasi muda dalam gerakan radikalisme dapat dilihat dalam beberapa kasus terorisme. sebagian besar pelaku aksi terorisme didapati merupakan pemuda dengan usia di antara 18-25 tahun. Dalam kasus trend ISIS didapati sekelompok remaja tanggung membaiat kelompok tersebut. Menurut Mayjen Agus SB (2016), asal perkembangan radikalisme di generasi muda dapat dikategorikan dari dua trend sumber. pertama sumber konvensional. Dimana dalam melalui sumber ini, penyebaran pemahaman radikal dapat berasal dari kontak orang per orang. Sedangkan sumber kedua adalah sumber non-konvensional. Dalam sumber non-konvensional ini tidak terlepas dari pengaruh media, khususnya media online.

Kemajuan media internet memungkinkan kelompok radikalis melakukan perekrutan, propaganda, dan penyebaran ideologi. Jika pada metode konvensional penyebaran paham radikalismeme diperlukan bertemu dengan perantara, maka metode tersebut kini dilengkapi dengan metode media online. Radikalisasi terjadi ketika seorang berhadapan dengan keyakinan dan ide radikal dan mengadopsi dalam bentuk tindakan. radikalisasi dipahami dalam bentuk proses individual, yaitu terbukanya kognitif terhadap ajaran dan tindakan tertentu. transformasi ini melewati beberapa fase dan tingkatan. Radikalisasi merupakan proses mencari, menemukan, mengadopsi, dan mengembangkan keyakinan dan yang ekstrim. keberadaan media online menjadi instrument yang berpotensi mempercepat proses radikalisasi tersebut.

Menurut Mayjen Agus SB (2016), media online menjadi strategis dalam pengembangan radikalisme karena media online menawarkan kebebasan dan keterbukaan. Setiap orang bebas mengakses sumber berita di media online. Media maya juga Melalui media maya, kejadian konflik di sebuah tempat dapat diberitakan saat itu juga ke tempat lain. Media juga berppotensi mengaburkan realita yang terjadi di lapangan serta membelokkan sesuai dengan ideologi dan nilai ekstrim lainnya. hal ini menyebabkan radikalisasi diri dapat bertumbuh besar. Dalam praktik lapangan, keberadaan media online tidak selalu menyebabkan generasi muda otomatis menjadi pengikut dari gerakan radikal. Namun diakui dalam banyak kasus terdapat proses 
radikalisasi kalangan generasi muda setelah mengakses situs online. Kegandrungan generasi muda mengakses dunia maya menyebabkan media menjadi faktor penting dalam perkembangan radikalisme di era kontemporer. Diperlukan sebuah sistem pendidikan yang dapat mengcounter kecenderungan ini.

Hal lain yang berkaitan adalah kondisi psikologis generasi muda. Kondisi psikologis generasi muda yang masih belum stabil memungkinkan pengaruh asing lebih mudah diterima oleh generasi muda. Dalam masa usia 12-25, generasi muda sedang mengalami masa pencarian jati diri. Masa ini sering ditandai ketidakstabilan emosi dan pemikiran. Segala bentuk pemikiran berpotensi dapat berkembang di masa ketika kondisi psikologis, emosi, dan pemikiran belum matang. Di satu sisi, pemikiran radikalisme seringkali menawarkan klaim kepastian dalam menjalani kehidupan. Untuk itulah, perlu diadakan pencegahan dan penanggulangan radikalisme ini agar tercipta suasana aman, nyaman, dan damai di negeri tercinta Indonesia.

\section{REFERENSI}

Banawiratma,J.B. 1993. Bersama Saudara-Saudari Beriman Lain: Perspektif Gereja Katolik, dalam Dialog: Kritik dan Identitas Agama Yogyakarta: Dian Interfidei.

Borradori, Giovanna. 2003. Philosophy in a time of Terror: Dialogues With Jurgen Habermas And Jacques Derrida. Chicago: The University of Chicago Press.

Echols, John M. dan Hassan Shadily. 1995. Kamus Inggris Indonesia. Jakarta: Gramedia.

Giddens, Anthony. 2002. Tradition dalam Runaway World: How Globalisation is Reshaping Our Lives. London: Profile Books.

Hendropriyono, A.M. 2009. Terorisme: Fundamentalis Kristen, Yahudi, Islam. Jakarta: Kompas Media Nusantara.

Juergensmeyer, Marx. 2002. Teror Atas Nama Tuhan : Kebangkitan Global Kekerasan Agama. Jakarta: Nizam Press \& Anima Publishing. 
SB, Agus. 2016. Deradikalisasi Nusantara: Perang Semesta Berbasis Kearifan Lokal Melawan Radikalisasi dan Terorisme. Jakarta: Daulat Press.

. 2016. Deradikalisasi Dunia Maya: Mencegah Simbiosis Terorisme dan Media. Jakarta: Daulat Press.

Schmidt, Eric \& Jared Cohen. 2014. The New Digital Age: Cakrawala Baru Negara, Bisnis, dan Hidup Kita. Jakarta: Kepustakaan Populer Gramedia.

Wittgenstein, Ludwig. 1983. Philosophical Investigations. Oxford: Basil Blackwell. 